kdy působil jako direktor filozofických, později matematicko-fyzikálních studií Karlo-Ferdinandovy univerzity. U disertací a jiných závěrečných prací vznikajících na pražské univerzitě v 17. a 18. století se běžně kromě defendenda uváděl i tzv. praeses, což byl profesor, který stanovil téma k obhajobě. Josef Stepling, jak je doloženo svědectvím patera Vydry, během svého úřadu tentamina schvaloval, někdy i redigoval. U těchto tisků jsou odkazy na signatury z Národní knihovny, místy i Strahovské knihovny, Památníku národního písemnictví atd. Archiv Univerzity Karlovy připomínán není bezpochyby proto, že katalog sbírky starých tezí a disertací není zpř́ístupněn v elektronické podobě.

Ačkoliv nehodlám předkládat prognostické soudy, které bývají mylné, domnívám se, že v budoucnu už nebude možno Steplingův portrét př́liš upřesnit; snad jenom podrobným studiem korespondence řádových generálů uložené v římském ústředním jezuitském archivu (ARSI). Tak by byly možná více osvětleny názory hodnostářu Tovaryšstva Ježíšova na muže, o němž pater Vydra píše, že „,byl často pronásledován a utlačován peripatetiky svého rrádu“ (s. 52). Mám vlastně vưči této velmi zdařilé publikaci jedinou výtku. Nelíbí se mi neobratný název, kde je užito nenáležitě zájmeno přivlastňovací ,jeho“. Vše by bylo v pořádku, kdyby název zněl: Josef Stepling (1716-1778) a jeho biografie a bibliografie. Bohužel nepatřričné tvary posesiv se staly v soudobé češtině běžným jevem. Nicméně hlavní autor knihy vystavěl z plodů svého badatelského úsilí nový pomník nejen Josefu Steplingovi, ale i sobě samotnému.

Ivana Čornejová

doi: $10.14712 / 23365730.2019 .26$

\title{
Jan Surman, Universities in Imperial Austria 1848-1918: A Social History of a Multilingual Space
}

Purdue University Press 2018, 460 s., ISBN 978-1557538376

Srovnávací dějiny vzdělání je disciplína, které se nevěnuje př́liš mnoho badatelů. Výraznou osobností na tomto poli je již delší dobu Jan Surman. Pod vlivem profesora vídeňské univerzity Mitchella G. Ashe rozvíjí srovnávací studia dějin univerzit v habsburské monarchii v novověku na širším základě. Surman napsal již řadu studií a předvedl konferenční prezentace, které směřují bud' $\mathrm{k}$ analýze jednotlivé univerzity, zejména $\mathrm{v}$ prostoru habsburské monarchie, obývané Slovany (Krakov, Lvov, Praha) a jejímu srovnání s vídeňským centrem, nebo mezi sebou navzájem. Díky tomu, že - v př́ípadě Prahy - stojí Surman mimo lokální badatelskou obec, má relativně dobrý nadhled nad českými podmínkami a odstup od možných interních subjektivních zkreslení.

Kniha „Universities in Imperial Austria 1848-1918: A Social History of a Multilingual Space“ je shrnutím a rozšířením Surmanových dosavadních studií. Věnuje se rozboru proměn univerzit $\mathrm{v}$ rámci habsburské monarchie po provedení tzv. thunovských (v širším kontextu nazývaných Exner-Bonitzových) reforem vzdělávacího systému. Jeho výzkum tady začíná již v předbřeznovém období (1. kapitola), kdy sumarizuje postavení univerzit od osvícenských reforem a jejich vývoj směrem k potřebě liberálnější reformy studia, vyvolané společenskou a politickou situací ve státě. Neutápí se ve zbytečných detailech. Sleduje politické, sociální i kulturní aspekty vývoje univerzit v celém časovém rozmezí, doplněné př́klady konkrétních lidí, aby předvedl určité typy akademiků, nebo naopak výjimky z celkové linie. 
V dalším oddíle práce se Surman věnuje ani ne tak průběhu reforem jako spíše přechodnému období padesátých let 19. století, kdy každá z tehdejších univerzit hledala cestu, jak se s novým systémem studia a organizace univerzity vypořádat a najít vlastní způsob uvedení změn do místní praxe.

Reformy měly dopad na celou vědeckou obec. Ukládaly pedagogům bádat a rozvíjet své obory a měly ambici povznést univerzity na úroveň vrcholných vědeckých pracovišt'. V univerzitních městech výrazně změnily vztahy mezi vysokými školami a dalšími tamějšími vědeckými institucemi jako byla muzea nebo učené společnosti. Ty byly - vedle středních škol - zpravidla platformou pro doplňování akademického stavu.

Zásadní hledisko analýzy, které se prolíná celou Surmanovou knihou, je jazyková otázka. Autor v ní vidí i hlavní specifikum univerzitního vývoje v celé habsburské monarchii (nejen) ve sledovaném časovém období. Po polovině 19. století rostou navzdory centralizačním tendencím Vídně rozdíly mezi vysokými učeními. Základním nástrojem zvětšování těchto rozdílů se stává právě vztah dané univerzity $\mathrm{k}$ němčině jako dosud povolenému vyučovacímu jazyku, který každá z nich řešila specifickým způsobem.

Státní jazyk - němčina - a jeho postavení při výuce a prosazování národních jazyků na mimovídeňských univerzitách je zásadní bod, který Surman podrobuje všestrannému rozboru. Sleduje lokální požadavky na zavedení národních jazyků do výuky, různé cesty jejich prosazení v Praze, Krakově a Lvově, dále se zabývá např. založením univerzity v Černovicích, národnostním složením jejích pedagogů a specifiky tohoto regionu. Od jazykové otázky se pak odvíjí vztah dané univerzity k vídeňskému centru. Proměňuje se i vztah mimovídeňských univerzit navzájem, ačkoli o jejich spolupráci jako celků - jak Surman mezi rádky ukazuje - nemůže být až do rozpadu rakousko-uherského soustátí řeč.

Velkou roli při formování studií hrála personální otázka obsazení stolic a vůbec struktura oboru na každé univerzitě. Surman proto věnuje značnou pozornost vysledování strategie habilitací - byla-li nějaká - na jednotlivých univerzitách a jmenování profesorů v dalším stupni obsazování tradičních i nově vznikajících oborů. Na konkrétním př́íkladu několika profesorů (s. 69 Pierre, Zawadski) dokládá i chaos v této otázce, který monarchie zažívala. Zásahy vídeňského ministerstva kultu a vyučování pak dopadaly na univerzity rovněž rozdílným způsobem, jak Surman opět detailně dokládá, se znalostí archivních pramenů, dobové preskriptivní literatury i legislativních norem.

Na př́kladech osudů a migrace některých profesorů ukazuje hierarchii univerzit, ale i výjimky a místní specifika, která se projevila při zaměření na některé obory (např. zemědělství na krakovské univerzitě, absence výuky rakouských dějiny na haličských univerzitách apod.). Pražské univerzitě, resp. po roce 1882 pražským univerzitám, je rovněž věnován velký prostor, v řadě aspektů dosud netematizovaný českou historiografií (např. kariérní imobilita profesorů české univerzity po roce 1882 na rozdíl od takřka všech ostatních univerzit $\mathrm{v}$ ř́ísi).

Surman při výzkumu používá významnou měrou kvantitativní metodu, a proto jeho kniha obsahuje řadu tabulek, které i vizuálně ukazují rozdíly nebo shody mezi univerzitami v řadě aspektů.

Surmanova kniha nemá hluchá místa, kde by si musel vypomáhat „,vatou“ bez obsahu. Je nabyta informacemi, které přinášejí nový pohled na strukturu a chod univerzit i na jejich postavení ve společnosti. Nanáší řadu otázek, které lze rozpracovat. Např. jeho teze o nepotkávání se „provincial“ a „imperial“ vědeckého prostředí kolem poloviny 19. století, které 
v leckterém ohledu vedlo k rozdílnému chápání reforem, by jistě bylo třeba ještě lépe vyargumentovat a podložit větším množstvím pramenů. Pro Prahu toto na základě dosavadních znalostí zcela neplatí, protože právě pražská univerzita i polytechnika, byt' ta byla zemským ústavem, resp. jejich (často společní) profesoři tehdy ještě měli velký zájem o spolupráci a propojenost s centrem (samožrejmě i zde lze najít výjimky - viz Bolzano) a o jednotnou linii vývoje. A platí to i naopak. Inspirace vídeňské polytechniky v době jejího založení tehdy jen pár let reorganizovanou pražskou polytechnikou je zcela zřejmá.

Kniha Jana Surmana v každém př́padě výrazně posunuje bádání o postavení vysokých škol v 19. a na počátku 20. století, v řadě pohledů je velmi nápaditá a př́nosná.

Milada Sekyrková doi: $10.14712 / 23365730.2019 .27$

\section{Soňa Štrbáňová, Bohuslav Raýman. Vědec, vlastenec a Evropan \\ Studie Národohospodářského ústavu Josefa Hlávky 1, Praha 2019, 296 s., ISBN 978-80-88018-23-0}

I v dějinách vědy existují osobnosti, o kterých se píše stále dokola, a osobnosti, které by si to zasloužily, ale dlouho nenajdou „svého“ iniciačního autora, který je uvede do povědomí. Soňa Štrbáňová vydanou monografí́ vyplnila jednu z těchto mezer, stala se Raýmanovou biografkou.

Neznamená to, že by se o něm nevědělo, jak dokazuje seznam literatury v knize. Kniha je presto první ucelenou monografí o profesoru Bohuslavu Raýmanovi (1852-1910), psanou s erudicí a se souhrnným pohledem na dostupné prameny a odbornou literaturu. Ostatně jejich vyhledání, navázání kontaktů s Raýmanovou rodinou, žijící v zahraničí, a přečtení kvanta korespondence, kterou Raýman psal i dostával a která je roztroušena v mnoha fondech, je jednou z velkých zásluh autorky.

Raýman je významným představitelem české vědy 2. poloviny 19. a počátku 20. století, jehož badatelský, pedagogický i organizační př́nos vývoji chemie, její výuce a propagaci je nezpochybnitelný.

Narodil se $\mathrm{v}$ roce $1852 \mathrm{v}$ Sobotce $\mathrm{v}$ rodině soudního úředníka. Po brzké smrti otce se matka s pěti dětmi přestěhovala do Mladé Boleslavi, kde chlapci navštěvovali gymnázium. Bohuslav pak pokračoval ve studiích dva roky na pražské polytechnice na chemickém odboru. Díky podpoře z př́buzenstva - jak právě dohledala Soňa Štrbáňová - mohl strávit další roky v Bonnu u prof. Augusta Kekulého a v Paříži o profesorů Adolfa Wurtze a Charlese Friedela, jedněch z největších kapacit v organické chemii jejich doby. Přestože měl možnost zůstat $\mathrm{v}$ zahraničí, kde by díky tomuto základu našel dobré uplatnění, vrátil se Raýman do Prahy. Přednášel nejprve na České vysoké škole technické a poté na filozofické fakultě české Karlo-Ferdinandovy univerzity, kde byl roku 1890 jmenován mimořádným a o sedm let později rádným profesorem organické chemie.

Angažoval se i v mnoha odborných institucích, např. po jejím vzniku působil jako tajemník II. (matematicko-přírodovědné tř́́dy) České akademie věd a umění a od roku 1899 až do své smrti jako generální sekretár̆ celé ČAVU. Jeho velké zásluhy spočívají kromě pedagogického působení a organizačního úsilí na vysokých školách a v akademii zejména v rozvíjení mezinárodních styků. Možná právě proto byl dosud u nás lehce opomíjen, 